\title{
Prospective randomised study of preoperative endoscopic sphincterotomy versus surgery alone for common bile duct stones
}

\author{
J P NEOPTOLEMOS, D L CARR-LOCKE, D P FOSSARD
}

\begin{abstract}
One hundred and twenty patients with known common bile duct stones were entered into a prospective randomised study of preoperative endoscopic sphincterotomy and stone clearance (group 1) versus surgery alone (group 2). Five patients were incorrectly entered; the 55 patients randomised to group 1 and the 60 randomised to group 2 were well matched with respect to clinical features and biochemical and medical risk factors. In group 1 endoscopic stone clearance was successful in 50 patients (91\%); five of these patients refused elective surgery, though this was subsequently necessary in one. In group 2 common bile duct stones were cleared surgically in 54 of 59 patients (91.5\%); one patient was treated by endoscopic sphincterotomy alone because of a myocardial infarct. The overall major complication rate in group 1 was $16.4 \%$ and included two deaths; in group 2 this was $8.5 \%$ and included one death. The minor complication rate in group 1 was $16.4 \%$ and that in group $213.6 \%$. These differences in outcome were not significant.

Despite a significant reduction in total hospital stay of patients in group 1 , these results do not support the routine use of preoperative endoscopic sphincterotomy in patients having biliary surgery for stones in the common bile duct.
\end{abstract}

\section{Introduction}

The mortality from cholecystectomy is less than $1 \% .^{1-3}$ By contrast, the mortality from surgery for stones in the common bile duct is of the order of $6 \%$ to $8 \%$ in unselected series of patients, ${ }^{24}$ though lower figures have been reported. ${ }^{135-7}$ Postoperative complications such as wound infection, intra-abdominal abscess, cholangitis, fistula, and renal failure may occur in up to $46 \%$ of patients. ${ }^{\prime}$ Factors which adversely affect outcome of surgery for suspected common bile duct stones include advanced age, ${ }^{348-11}$ obstructive jaundice, ${ }^{10-12}$ biliary sepsis, ${ }^{11-14}$ and the confirmed presence of stones. ${ }^{2411}$ 15 Other biochemical and medical risk factors have also been identified..$^{8-10} 14$

Modern experience with endoscopic sphincterotomy has shown that clearance of stones from the common bile duct may be achieved in about $90 \%$ of patients with a complication rate of about $10 \%$ and mortality of around $1 \cdot 5 \%{ }^{16} 17$ Thus endoscopic sphincterotomy has become established in the management of retained or recurrent stones after cholecystectomy and in very elderly high risk patients with the gall bladder in situ..$^{16-18}$ Most patients with stones in the common bile duct require surgery, however, and it has been proposed that preoperative endoscopic sphincterotomy in these patients might be a better alternative than surgery alone. In a preliminary non-randomised study the advantages of this approach versus surgery were inconclusive. ${ }^{19}$ We report a prospective randomised study comparing these two methods of treatment.

Leicester Royal Infirmary, Leicester

J P NEOPTOLEMOS, MD, FRCS, senior registrar in surgery

D L CARR-LOCKE, MA, MRCP, consultant physician in gastroenterology

D P FOSSARD, $\mathrm{MCH}$, FRCS, consultant in general surgery

Correspondence to: Mr J P Neoptolemos, Department of Surgery, Clinical Sciences Building, Leicester Royal Infirmary, PO Box 65, Leicester LE2 7LX.

\section{Patients and methods}

Between April 1981 and December 1985, 120 patients with stones in $\stackrel{\mathbb{Q}}{\Omega}$ the common bile duct were entered into a prospective study in which \& patients were allocated to have either endoscopic stone extraction followed $\vec{\bullet}$ by surgery (group 1) or surgery alone (group 2). Allocation was by random numbers. The diagnosis was established by endoscopic retrograde $\overrightarrow{\vec{\omega}}$ cholangiopancreatography in 113 patients, ultrasonography in six, and $\omega_{\sigma}$ percutaneous transhepatic cholangiography in one. Patients were excluded $\vec{T}$ if they were unfit for surgery, had undergone previous cholecystectomy, or 3 . were pregnant. If suitable for entry patients were randomised to the N treatment group as soon as the diagnosis of stones was made. In group 1. endoscopic sphincterotomy was undertaken at the same time as endoscopic of retrograde cholangiopancreatography, if this was the method of diagnosis, or on the next available list for endoscopic retrograde cholangiopancreatography if the diagnosis was by ultrasonography or percutaneous transhepatic cholangiography (there were two lists for endoscopic retrograde cholangiopancreatography each week). For patients in group 2 surgery was undertaken on the next available operating list after suitable preoperative $N$ preparation.

Endoscopic retrograde cholangiopancreatography and endoscopic stone extraction after sphincterotomy were performed by a single endoscopist (DC-L) using Fujinon DUO-X and DUO-XL side viewing duodenoscopes and a Classen-Demling sphincterotome with an Erbotom T175D diathermy unit. ${ }^{18}$ All patients with jaundice were rehydrated with intravenous crystalloid $\vec{\varnothing}$ solutions for at least 24 hours before surgery and began a mannitol diuresis at the start of surgery. The operations were undertaken by a consultant $\square$ surgeon or senior surgical registrar. Cephazolin $1 \mathrm{~g}$ intravenously or intramuscularly was given as prophylaxis before endoscopic sphincterotomy and surgery. Patients with acute cholangitis were given intravenous metronidazole, penicillin, and gentamicin. Bile from the gall bladder was taken at the time of surgery for routine bacterial culture.

The two groups were compared according to clinical, biochemical, and $\vec{\Rightarrow}$ medical "risk" factors using a modification of previously-described systems $\frac{}{3}$ (table I) ${ }^{8-1014}$ No attempt was made to stratify patients prospectively for $\frac{}{J}$ these prerecorded risk factors, which accordingly were analysed after the study. Outcome was assessed in terms of mortality, major (life threatening) morbidity, minor (non-life threatening) morbidity, and length of hospital stay. Patients were followed up for a minimum of six months.

TABLE I-Risk factors

\begin{tabular}{lll}
\hline Major & \multicolumn{1}{c}{ Minor } & Medical \\
\hline $\begin{array}{l}\text { Bilirubin }>100 \mu \mathrm{mol} / 1 \\
\text { Packed cell volume }<0.30\end{array}$ & $\begin{array}{l}\text { Age }>60 \\
\text { Alkaline phosphatase }>130 \mathrm{IU} / 1\end{array}$ & $\begin{array}{l}\text { Heart disease } \\
\text { Creatinine }>130 \mu \mathrm{mol} / 1\end{array}$ \\
$\begin{array}{l}\text { Alanine transaminase }>100 \mathrm{IU} / 1 \\
\text { Albumin }<30 \mathrm{~g} / 1\end{array}$ & $\begin{array}{l}\text { Respiratory disease } \\
\text { Temperature }>38^{\circ} \mathrm{C}\end{array}$ \\
$\begin{array}{l}\text { White cell count }>10 \times 10^{9} / 1 \\
\text { Diabetes mellitus }\end{array}$ & \\
\hline
\end{tabular}

Statistical analysis-Continuous variables were analysed by the MannWhitney U test using the Minitab computer program. Discrete variables were analysed by the $\chi^{2}$ test and $\chi^{2}$ test with Yates's correction for expected $\bar{O}$ small numbers. $p$ Values are given only where differences were significant, $\overrightarrow{\mathbb{D}}$ taken as $\mathrm{p}<0.05$. Where appropriate $95 \%$ confidence intervals were $\overrightarrow{\mathbb{D}}$ calculated. Because of ethical considerations provision was made to terminate the study in two circumstances. Firstly, it was to be stopped if there was an unacceptably high complication rate in either group compared with the other with a probability of $p<0 \cdot 01$. Secondly, it was to be stopped if there was a very high probability $(p<0.0001)$ that the new treatment (preoperative endoscopic sphincterotomy) was not going to achieve a significantly superior result compared with conventional treatment (surgery alone), given that a 
large proportion of patients had been entered and the two groups were comparable with respect to risk factors. The possibility of achieving a significant result was determined by taking extreme events leading to significant end points $(p<0.05)$ using $\chi^{2}$ and then summing binomial probabilities, calculated from events leading to these significant end points.

\section{Results}

Of the 120 patients, five were incorrectly entered into the trial; two had a complicated diagnosis (cholangiocarcinoma and acute appendicitis with liver abscess, respectively), one was under the care of a consultant not participating in the trial, one refused operation, and another refused endoscopic retrograde cholangiopancreatography. Thus there were 55 patients in group 1 and 60 in group 2 who were available for analysis. The two groups compared well with respect to clinical features and number of risk factors (table II) and similarly with respect to biochemical features (table III). There were no significant differences between the groups except that clinical jaundice was more common in group 2 (table II), though there was no significant difference in serum bilirubin concentrations on admission

TABLE II-Presenting clinical features and risk factors in the two treatment groups

\begin{tabular}{llc}
\hline & $\begin{array}{c}\text { Group } 1 \\
(\mathbf{n}=55)\end{array}$ & $\begin{array}{c}\text { Group 2 } \\
(\mathbf{n}=59)\end{array}$ \\
\hline No (\%) women & $26(47)$ & $35(59)$ \\
Median age in years (range) & $61(20-83)$ & $59(20-82)$ \\
No(\%) with pain & $48(87)$ & $57(97)$ \\
No(\%) with jaundice & $35(64)$ & $52(88)$ \\
No(\%) with fever $>38^{\circ} \mathrm{C}$ & $11(20)$ & $17(29)$ \\
No(\%) with acute cholangitis & $4(7)$ & $9(15)$ \\
No(\%) with acute pancreatitis & $3(5)$ & $1(2)$ \\
Median No of major risk factors (range) & $1(0-3)$ & $1(0-3)$ \\
Median No of all risk factors (range) & $3(0-8)$ & $3(0-8)$ \\
\hline
\end{tabular}

Significance of difference between groups for clinical jaundice: $\chi^{2}=9 \cdot 45 ; \mathrm{df}=1 ; \mathrm{p}=0 \cdot 002$.
TABLE III-Biochemical features in the two groups. Values are medians (ranges in parentheses)

\begin{tabular}{|c|c|c|}
\hline & $\begin{array}{c}\text { Group 1 } \\
(\mathbf{n}=55)\end{array}$ & $\begin{array}{r}\text { Group 2 } \\
(\mathrm{n}=60)\end{array}$ \\
\hline Bilirubin $(\mu \mathrm{mol} / \mathrm{l})$ & $71(3-372)$ & $110(7-474)$ \\
\hline Haemoglobin $(\mathrm{g} / \mathrm{l})$ & $143(100-167)$ & $137(105-175)$ \\
\hline Packed cell volume & $0.42(0 \cdot 29-0.49)$ & $0.41(0.33-0.67)$ \\
\hline Urea $(\mathrm{mmol} / \mathrm{l})$ & $4 \cdot 5(2 \cdot 0-19 \cdot 0)$ & $4 \cdot 1(2 \cdot 1-10 \cdot 5)$ \\
\hline Creatinine $(\mu \mathrm{mol} / \mathrm{l})$ & $86 \cdot 0(45-280)$ & $82 \cdot 5(53-193)$ \\
\hline Albumin $(g / 1)$ & $40 \cdot 0(26-48)$ & $38 \cdot 5(26-50)$ \\
\hline White cell count $\left(\times 10^{9} / 1\right)$ & $8 \cdot 3(2 \cdot 5-21 \cdot 8)$ & $9 \cdot 4(3 \cdot 9-21 \cdot 8)$ \\
\hline Alkaline phosphatase (IU//) & $360(62-2629)$ & $347(72-1506)$ \\
\hline Alanine transaminase (IU/I) & $134(12-1134)$ & $158(11-888)$ \\
\hline$\gamma$-Glutamyltransferase (IU/l) & $290(11-1213)$ & $297(10-1891)$ \\
\hline
\end{tabular}

There were no significant differences between groups.

(table III). The figure shows the initial fate of the patients randomised into the study.

\section{GROUP 1}

\section{Endoscopic sphincterotomy}

Successful endoscopic sphincterotomy was performed in 53 patients (96\%) with immediate stone extraction in 44 patients and complete extraction after a second endoscopic sphincterotomy in another patient. Persisting stones passed spontaneously in a further five patients, resulting in an overall clearance of $91 \%$. Twenty four patients (44\%) were found to have multiple common bile duct stones.

Important complications occurred in five patients ( $9 \%$ ) after endoscopic sphincterotomy. Three patients had acute cholangitis, one of whom had an associated attack of acute pancreatitis, and a fourth patient had a major retroperitoneal perforation of the common bile duct with septicaemia. Blood cultures were positive in these patients; the main organisms were Klebsiella

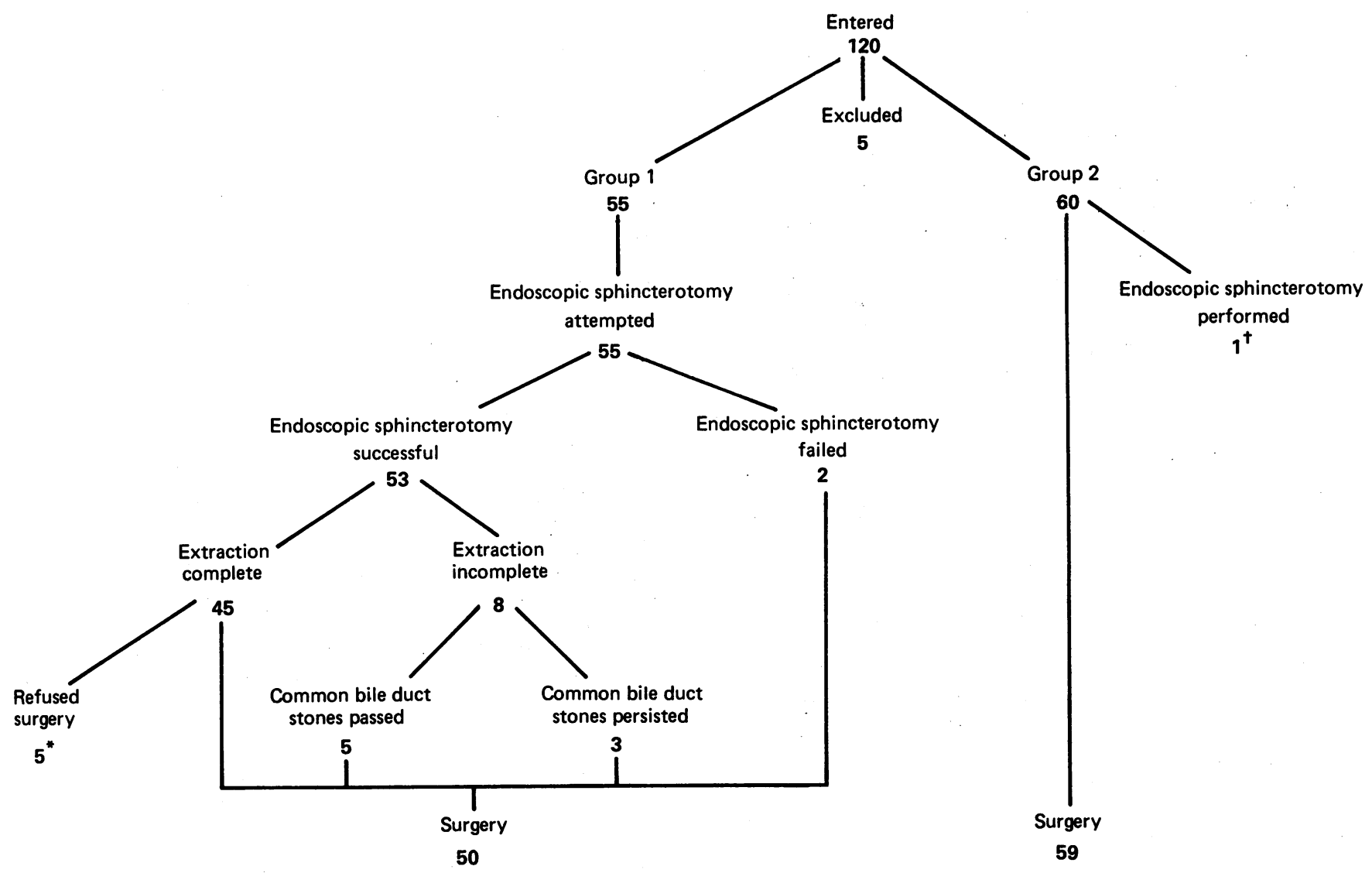

Fate of 120 patients entered into study.

*One patient subsequently had cholecystectomy for recurrent acute cholecystitis.

$\dagger$ This patient developed myocardial infarction after endoscopic retrograde cholangiopancreatography and was excluded from surgery. 
pneumoniae in two patients, Pseudomonas aeruginosa in one, and Enterobacter cloacae in one. A fifth patient had an attack of acute pancreatitis alone.

Of the 55 patients in group 1, five who had had successful endoscopic stone extraction refused to proceed to cholecystectomy. Four of these patients (aged 74, 78, 62, and 82) remained well at two to four year follow up. The other patient, a 52 year old with cardiorespiratory disease, had surgery 18 months after endoscopic sphincterotomy because of repeated attacks of acute cholecystitis. This patient survived a stormy postoperative course complicated by respiratory failure.

\section{Surgery}

In the 50 patients who agreed to proceed to elective surgery the median interval between endoscopic sphincterotomy and surgery was five days (range one to 117 days). The median serum bilirubin concentration before endoscopic retrograde cholangiopancreatography and endoscopic sphincterotomy was 71 (range 3-372) $\mu \mathrm{mol} / \mathrm{l}$, which fell to 18 (3-412) $\mu \mathrm{mol} / 1$ $(p=0.0019$; Mann-Whitney $U$ test) after endoscopic sphincterotomy but before surgery (including values from patients in whom endoscopic sphincterotomy was unsuccessful).

All patients underwent cholecystectomy, and peroperative cholangiography was performed in $43(86 \%)$. The operation was performed by a consultant in 39 patients (78\%). Five patients with failed endoscopic stone clearance underwent choledocholithotomy. Two patients had supraduodenal exploration with insertion of a $\mathrm{T}$ tube, one had a choledochoduodenostomy, and two had transduodenal exploration with conversion of the endoscopic sphincterotomy to a transduodenal sphincteroplasty. Two other patients had choledocholithotomy because stones had passed from the gall bladder into the common bile duct after initial endoscopic clearance. The time intervals between endoscopic sphincterotomy and surgery in these two patients were 55 and 71 days, respectively: One of these patients had a supraduodenal exploration with $T$ tube insertion and the other had combined supraduodenal exploration with $T$ tube insertion and transduodenal exploration. Three patients had a negative supraduodenal exploration with $\mathrm{T}$ tube insertion because of suspected stones on peroperative cholangiography. A further two patients had a $\mathrm{T}$ tube inserted because of inadvertent choledochotomy.

Seven patients (14\%) had major postoperative complications, two of whom died (table IV). Eight patients (16\%) had minor postoperative complications, which included seven wound infections (five with positive culture) and two incisional hernias.

The combined endoscopic sphincterotomy and operative major complication rate in all 55 patients in group 1 was $16.4 \%$ (9/55; confidence interval $6 \cdot 6-26 \cdot 2 \%)$ and the combined minor morbidity overall was also $16 \cdot 4 \%(9 / 55$; confidence interval $6 \cdot 6-26 \cdot 2 \%$ ). The total complication rate in group 1 was thus $33 \%$. Complications were not related to the interval between endoscopic sphincterotomy and surgery, nor to the seniority of the surgeon. Complications were, however, significantly related to the failure of initial (preoperative) endoscopic stone clearance. Specifically, complications occurred in one of two patients in whom endoscopic sphincterotomy failed, in the one patient who had two preoperative endoscopic procedures, in one of three patients with persisting stones in the common bile duct, and in four of the five patients in whom stones passed spontaneously. Thus complications occurred in seven of these 11 patients, compared with only 11 complications in the 44 patients in whom stone clearance was successful from the outset $\left(\chi^{2}=4 \cdot 34 ; \mathrm{df}=1 ; p=0 \cdot 038\right)$.

TABLE IV-Major complications in group 1

\begin{tabular}{|c|c|c|c|}
\hline $\begin{array}{l}\text { Case } \\
\text { No }\end{array}$ & $\begin{array}{l}\text { Associated endoscopic } \\
\text { complications }\end{array}$ & $\begin{array}{l}\text { Bile duct } \\
\text { surgery }\end{array}$ & $\begin{array}{l}\text { Postoperative } \\
\text { complications }\end{array}$ \\
\hline 1 & $\left\{\begin{array}{l}\text { Retroperitoneal perforation, } \\
\text { failed stone clearance } \\
\text { Septicaemia }\end{array}\right.$ & $\begin{array}{l}\text { Supraduodenal } \\
\text { exploration } / \mathrm{T} \text { tube }\end{array}$ & $\begin{array}{l}\text { Respiratory } \\
\text { failure } \\
\text { Death }\end{array}$ \\
\hline 2 & Acute cholangitis & None & $\begin{array}{l}\text { Wound infection; } \\
\text { burst abdomen }\end{array}$ \\
\hline 3 & $\left\{\begin{array}{l}\text { Acute cholangitis } \\
\text { Acute pancreatitis }\end{array}\right.$ & Supraduodenal exploration $/ \mathrm{T}$ tube & $\begin{array}{l}\text { Acute cholangitis } \\
\text { Lumbar discitis }\end{array}$ \\
\hline 4 & $\begin{array}{l}\text { "Recurrent" common bile } \\
\text { duct stone }\end{array}$ & $\begin{array}{l}\text { Supraduodenal } \\
\text { exploration/T tube }\end{array}$ & $\begin{array}{l}\text { Intra-abdominal } \\
\text { abscess }\end{array}$ \\
\hline 5 & None & None & Biliary leak \\
\hline 6 & None & T tube & $\begin{array}{l}\text { Respiratory failure. } \\
\text { Death }\end{array}$ \\
\hline 7 & None & None & $\begin{array}{l}\text { Wound infection; } \\
\text { burst abdomen }\end{array}$ \\
\hline 8 & $\left\{\begin{array}{l}\text { Acute cholangitis } \\
\text { Failed stone clearance }\end{array}\right.$ & $\begin{array}{l}\text { Supraduodenal exploration/T tube } \\
\text { Transduodenal sphincteroplasty }\end{array}$ & None \\
\hline 9 & Acute pancreatitis & None & Operation refused \\
\hline
\end{tabular}

GROUP 2

All but one of the patients in group 2 had surgery as planned. The exception was a 54 year old who sustained a myocardial infarct several days after endoscopic retrograde cholangiopancreatography and was not operated on. The patient subsequently had endoscopic stone clearance and died a year later from another infarct.

All 59 patients who had surgery underwent cholecystectomy, and 37 patients $(63 \%)$ also had peroperative cholangiography. Multiple common bile duct stones were present in 32 patients $(54 \%)$. Thirty seven of the operations (63\%) were performed by consultants. Transduodenal sphincteroplasty was performed in 16 patients, of whom six also had supraduodenal exploration and insertion of a $T$ tube and six others choledochoduodenostomy. The other 37 patients had supraduodenal exploration with $\mathrm{T}$ tube insertion.

Stones were left in the common bile duct in five patients $(8.5 \%)$, four of the operations being performed by consultants. Three operations included combined transduodenal sphincteroplasty and supraduodenal exploration with $\mathrm{T}$ tube insertion, and the other two operations were supraduodenal exploration with a $\mathrm{T}$ tube. Incomplete stone clearance was suspected in four of the five patients. These patients were subsequently successfully treated by endoscopic sphincterotomy in four cases and infusion of mono-octanoin through a $T$ tube in the fifth case. Another patient presented with a recurrent common bile duct stone four years after surgery, which also was removed endoscopically.

Five patients $(8 \cdot 5 \%$; confidence interval $1 \cdot 4-15 \cdot 6 \%)$ had major postoperative complications (table $\mathbf{V}$ ), including a single fatal case of haemorrhagic pancreatitis in a patient with Nelson's syndrome (after adrenalectomy). Eight patients (13.6\%; confidence interval $4 \cdot 9-22 \cdot 3 \%)$ had minor complications, all of which were wound infections (culture positive in seven cases). Complications were unrelated to the seniority of the surgeon. The outcome in the two groups (summarised in table VI) did not reach statistical significance.

TABLE V-Major postoperative complications in group 2

\begin{tabular}{|c|c|c|}
\hline $\begin{array}{l}\text { Case } \\
\text { No }\end{array}$ & Bile duct surgery & Postoperative complications \\
\hline $\begin{array}{l}10 \\
11 \\
12 \\
13 \\
14\end{array}$ & $\begin{array}{l}\text { Transduodenal sphincteroplasty } \\
\text { Choledochoduodenostomy } \\
\text { Supraduodenal exploration of common duct } / \mathrm{T} \text { tube } \\
\text { Supraduodenal exploration of common duct/T tube } \\
\text { Choledochoduodenostomy }\end{array}$ & $\begin{array}{l}\text { Haemorrhagic pancreatitis. Death } \\
\text { Biliary leak } \\
\text { Acute pancreatitis } \\
\text { Intra-abdominal abscess } \\
\text { Biliary leak }\end{array}$ \\
\hline
\end{tabular}

TABLE VI-Overall complications in both groups, expressed as number (percentage) of patients

\begin{tabular}{lccc}
\hline & Major & Minor & Total \\
\hline Group $1(n=55)$ & $9(16 \cdot 4)$ & $9(16 \cdot 4)$ & $18(32 \cdot 7)$ \\
Group 2 $(\mathrm{n}=59)$ & $5(8 \cdot 5)$ & $8(13 \cdot 6)$ & $13(22 \cdot 0)$ \\
\hline$\chi^{2}$ & $1 \cdot 50$ & $0 \cdot 18$ & $1 \cdot 64$ \\
df & 1 & 1 & 1 \\
p Value & $0 \cdot 22$ & $0 \cdot 67$ & $0 \cdot 20$ \\
$95 \%$ Confidence limits of difference (\%) & $-4 \cdot 2,20 \cdot 0$ & $-3 \cdot 9,9 \cdot 5$ & $2 \cdot 3,19 \cdot 3$ \\
\hline
\end{tabular}

\section{GALL BLADDER BILE CULTURE}

Gall bladder bile was cultured in 29 patients (58\%) in group 1 and in 43 patients $(73 \%)$ in group 2 . Though bile sampling was not undertaken in all patients because of failure to adhere to the study protocol (without apparent bias), we nevertheless considered that the results should be reported. The incidence of positive cultures was significantly higher in group 1 (table VII), and pseudomonas was also more frequently found in this group (table VIII).

\section{LENGTH OF STAY IN HOSPITAL}

The median time between operation and discharge from hospital, excluding deaths, was nine (range four to 57 ) days in group 1 compared with 11 (six to 27) days in group $2(p=0.0012$; Mann-Whitney $U$ test). The tota hospital stay, from the first day of admission, was 16 (nine to 59) days in group 1 and 21 ( 10 to 52 ) days in group 2 ( $p=0.0065 ;$ Mann-Whitney $U$ test). 
(Eight of the patients in group 1 were discharged from hospital after successful endoscopic sphincterotomy and subsequently readmitted for elective surgery.)

\section{TRIAL SIZE}

We had estimated that a minimum of 79 patients in each group would be required to show a reduction in overall morbidity from $40 \%$ in the conventionally treated group to $20 \%$ in the group treated preoperatively with endoscopic sphincterotomy $(\alpha 0.05 ; \beta 0.2)$. After 120 patients had been entered into the study we calculated that if the trial was to be continued the probability of the new treatment becoming significantly better than the conventional treatment was extremely small $\left(p \approx 3 \times 10^{-9}\right.$, binomial probabilities). Given that there were important ethical considerations in constraining the use (or non-use) of preoperative endoscopic sphincterotomy for the trial, along with the low probability of achieving a statistically significant end point, we decided that the trial should not be continued.

TABLE VII-Results of gall bladder bile culture

\begin{tabular}{lcccc}
\hline & \multicolumn{3}{c}{ No of organisms } & Culture \\
\cline { 2 - 5 } & 1 & 2 & 3 & sterile \\
\hline Group 1 $(n=29)$ & 11 & 8 & 2 & 8 \\
Group 2 $(n=43)$ & 11 & 8 & 1 & 23 \\
\hline
\end{tabular}

Significance of difference between groups: $\chi^{2}=$ $4 \cdot 74 ; \mathrm{df}=1 ; \mathrm{p}=0 \cdot 03$.

\begin{tabular}{|c|c|c|}
\hline $\begin{array}{l}\text { Gall bladder bile } \\
\text { organism }\end{array}$ & $\begin{array}{l}\text { Group } 1 \\
(n=29)\end{array}$ & 1 Group 2 \\
\hline $\begin{array}{l}\text { Escherichia coli } \\
\text { Pseudomonas spp } \\
\text { Klebsiella spp } \\
\text { Streptococcus faecalis } \\
\text { Proteus spp } \\
\text { Bacteroides spp }\end{array}$ & $\begin{array}{r}16 \\
6 \\
6 \\
4 \\
1 \\
0\end{array}$ & $\begin{array}{r}17 \\
1 \\
3 \\
5 \\
1 \\
3\end{array}$ \\
\hline \multicolumn{3}{|c|}{$\begin{array}{l}\text { Significance of difference between } \\
\text { groups for numbers of times } P \text { seudo- } \\
\text { monas spp was grown: } \chi^{2}=4 \cdot 81 ; \mathrm{df}=1 ; \\
\mathrm{p}=0.03 \text {. }\end{array}$} \\
\hline
\end{tabular}

\section{Discussion}

In this trial preoperative endoscopic sphincterotomy and stone clearance did not reduce morbidity compared with a conventional surgical approach. All patients had stones in the common bile duct, $76 \%$ were clinically jaundiced, $51 \%$ were aged 60 or more, and $49 \%$ had multiple stones. Surprisingly few surgical series of consecutive patients have given the detailed information provided in this study, so that only broad comparisons are possible. Results have usually been expressed with respect to all explorations of the common bile duct irrespective of the incidence of stones found, but where this information is discernible it is evident that mortality ${ }^{2415}$ as well as other complications ${ }^{11}$ are appreciably higher in patients with confirmed choledocholithiasis. Both groups compared favourably with respect to biochemical and medical risk factors, though there was a predominance of clinically jaundiced patients in the surgery only group (group 2). For the large part these risk factors have been developed in series consisting of patients with both benign and malignant disease, ${ }^{8.10}$ but recently this approach has been extended to patients with acute cholangitis and stones in the common bile duct. ${ }^{14}$ In this latter study medical risk factors as defined in our trial were shown to have a significant effect on mortality.

The clearance rate of stones in the common bile duct of $91 \%$ achieved by endoscopic sphincterotomy in group 1, though not as high as reported in a larger, personal series, ${ }^{20}$ compares very favourably with the results of others. ${ }^{16} 17$ The clearance rate by surgery alone (group 2) was $92 \%$. The proportion of patients having surgical exploration of the common bile duct who turn out to have stones is of the order of only $70-80 \%{ }^{6721}$ or lower. ${ }^{241522}$ Thus the rate of retained stones after positive explorations may be $6-10 \%$ or higher, ${ }^{14} 1{ }^{21} 22$ and it is these figures with which our study must be compared. A retained stone rate of $5 \%$ or less is attainable by the use of choledochoscopy, ${ }^{67}$ though this is by no means universal, even in the hands of "experts." 1522 In our study endoscopic sphincterotomy and surgical exploration were comparable in clearing stones from the common bile duct. Though there were no retained stones postoperatively in group 1, this was at the expense of an endoscopic sphincterotomy in all of these patients. Follow up studies of one to seven years in patients who have undergone endoscopic sphincterotomy show that $4 \cdot 4 \%$ to $9 \cdot 8 \%$ of these patients develop papillary stenosis, or new stones, or both. ${ }^{16}{ }^{17}$ Though there were five patients with retained stones after conventional treatment, these were readily treated (in four by endoscopic sphincterotomy). Follow up results of patients who have had surgical exploration of the common bile duct suggest an incidence of long term complications, including recurrent stones, of $5 \%$ or less. ${ }^{23-25}$

Preoperative endoscopic sphincterotomy in jaundiced patients might be expected to be beneficial by relieving the jaundice, which may result in impaired renal function, reduced hepatic endotoxin clearance, and a bleeding tendency. ${ }^{12}$ In order to produce a clinical benefit, however, the advantages of relieving the jaundice must be significantly higher than the potential complications of the drainage procedure itself.

The overall complication rate for endoscopic sphincterotomy is generally reported to be around $10 \%, 1620$ which clearly weakens the effectiveness of the preoperative treatment policy. In this study the complication rate was $9 \%$ from well recognised causes (cholangitis, pancreatitis, and perforations) but there was no case of appreciable haemorrhage, which usually accounts for about half of the complications. ${ }^{20}$

A main reason for the failure of preoperative percutaneous biliary drainage to influence the outcome of surgery (largely in patients with malignant disease) has been the development of biliary sepsis. ${ }^{26}$ Complications from biliary surgery commonly relate to the presence of infected bile. ${ }^{1127}$ In this study a higher incidence of infected gall bladder bile was shown in patients who had undergone endoscopic sphincterotomy compared with those who had surgery alone despite the larger proportion of patients among the latter who presented with jaundice or who, in addition, had acute cholangitis. Though gall bladder bile sampling was incomplete in this study, Gregg et al similarly showed that $33(73 \%)$ of 45 patients developed infected bile after endoscopic sphincterotomy or surgical sphincteroplasty, even though all the patients had had sterile bile previously. ${ }^{28}$ Pseudomonas organisms are not commonly found in the bile of patients with gall stones, ${ }^{29}$ and the frequency with which they were found in group 1 suggests their introduction after endoscopic sphincterotomy, but further studies are required to confirm this.

The proportion of patients with minor complications was similar in the two groups $(16.4 \%$ in group $1,13.6 \%$ in group 2$)$. Though not statistically significant, the proportion of patients with major complications was higher in the preoperative endoscopic sphincterotomy group $(16.4 \% v 8.5 \%)$. Three of the patients who developed major postoperative complications in this group had developed severe septic complications as a direct result of endoscopic sphincterotomy. It was also clearly established that those patients who did not have their bile ducts completely cleared of stones at initial endoscopy were those who were most likely to have complications.

Wound infections or intra-abdominal sepsis (unrelated to bile leaks) occurred in $19(17 \cdot 3 \%)$ of the 110 patients who underwent surgery and reflect the inadequacy of current antibiotic prophylaxis for this group of patients. Though cephazolin has been shown to be effective in routine biliary surgery, this has not been so in patients with obstructive jaundice. ${ }^{30}$

In the past few decades there has been a trend in favour of a 
reduction in the mortality from surgery for stones in the common bile duct. ${ }^{2}$ The increasing use of endoscopic sphincterotomy to remove stones without subsequent cholecystectomy in high risk patients ${ }^{1618}$ should accelerate this trend. There are several recent series of explorations of the common bile duct in elective cases with a mortality of $2 \%$ or less, ${ }^{3132}$ and this level of achievement should be approachable on a wider scale. In this trial the mortality of $1.7 \%$ in the conventionally treated group goes some way towards this. As this low mortality rate closely approximates that of endoscopic sphincterotomy we doubt whether a substantial reduction in mortality can be achieved by using preoperative endoscopic sphincterotomy in all patients. (A trial of over 6000 patients would be required to show a significant difference.)

Though there was a reduction in the mean hospital stay of patients in group 1 the difference was not large enough to justify the adoption of preoperative endoscopic sphincterotomy for this reason alone. Nevertheless, there are definite advantages in using this approach in those patients with a concurrent medical condition which can be improved on before cholecystectomy. Furthermore, there are other, more readily defined subgroups of patients, such as those with acute cholangitis ${ }^{14}$ or severe biliary pancreatitis, ${ }^{33}$ who may well benefit from this approach.

In conclusion, though we would not recommend the routine use of preoperative endoscopic stone extraction, this can be a useful method of management and will undoubtedly become widely established, albeit with a limited role.

We are extremely grateful to all the consultant surgeons in Leicester who made this trial possible. In particular we thank Mr D Watkin and $\mathrm{Mr} \mathrm{N}$ Everson, who as well as contributing a large proportion of patients also made valuable comments about the manuscript. We acknowledge the statistical advice of Dr David Shaw. Finally, we thank Rosalind Aldwinckle for secretarial work.

\section{References}

1 Crumplin MKH, Jenkinson LR, Kassab JY, Whitaker CM, Al-Boutahi FH. Management of gallstones in a district general hospital. Brf Surg 1985;72:428-32.

2 Doyle PJ, Ward-McQuaid JN, McEwen Smith A. The value of routine per-operative cholangiography-a report of 4,000 cholecystectomies. Brf Surg 1982;69:617-9.

3 McSherry CK, Glenn F. The incidence and causes of death following surgery for non-malignant biliary tract disease. Ann Surg 1980;191:271-5.

4 Vellacott KD, Powell PH. Exploration of the common bile duct: a comparative study. $B r \mathcal{F} S$ urg 1979;66:389-91.

Antrum RM, Hall R. Transduodenal sphincteroplasty: an analysis of 118 consecutive cases. $\mathrm{Br} \mathcal{J}$ Surg 1984;71:446-8.

6 Escat J, Glucksman DL, Maigne C, et al. Choledochoscopy in surgery for choledocholithiasis. Six year experience in 380 consecutive patients. Am $\mathcal{F}$ Surg 1984;147:670-1.

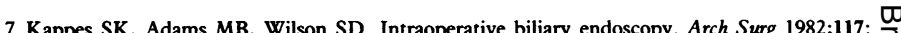

8 Blamey SL, Fearon KCH, Gilmour WH, Osborne DH, Carter DC. Prediction of risk in biliary surgery. Brf Surg 1983;70:535-8.

9 Dixon JM, Armstrong CP, Duffy SW, Davies GC. Factors affecting morbidity and mortality after $C$ surgery for obstructive jaundice: a review of 373 patients. Gut 1983;24:845-52.

10 Pitt HA, Cameron JL, Postier RG, Gadacz TR. Factors affecting mortality in biliary tract surgery. Am f Surg 1981;141:66-71.

11 Keighley MRB, Flinn R, Alexander-Williams J. Multivariant analysis of clinical and operative J findings associated with biliary sepsis. Br $\mathcal{F}$ Surg 1976;63:528-31.

12 Pain JA, Cahill CJ, Bailey ME. Perioperative complications in obstructive jaundice: therapeutic consideration. Brf Surg 1985;72:942-5.

13 Thompson JE, Tompkins RK, Longmire WP. Factors in the management of acute cholangitis. Ann Surg 1982;195:137-45.

14 Leese T, Neoptolemos JP, Baker AR, Carr-Locke DL. The management of acute cholangitis and $\overrightarrow{\overline{\bar{N}}}$ the impact of endoscopic sphincterotomy. Br F Surg 1986;73:988-92.

15 Feliciano DV, Mattox KL, Jordan GL. The value of choledochoscopy in exploration of the common bile duct. Ann Surg 1980;191:649-53.

16 Escourrou J, Cordova JA, Lazorthes F, Frexinos J, Ribet A. Early and late complications after endoscopic sphincterotomy for biliary lithiasis with and without the gallbladder in situ. Gut 1984;25:598-602.

17 Cotton PB. Endoscopic management of bile duct stones (apples and oranges). Gut 1984;25: 은 587-97.

18 Neoptolemos JP, Carr-Locke DL, Fraser I, Fossard DP. The management of common bile duct $\rightarrow$ calculi by endoscopic sphincterotomy in patients with gallbladders in situ. $\mathrm{Br} \mathcal{J}$ Surg $\vec{O}$ 1984;71:69-71.

19 Neoptolemos JP, Carr-Locke DL, Fossard DP, Hall AW. Endoscopic sphincterotomy prior to $\vec{\omega}$ surgery for common bile duct caluli. Langenbecks Arch Chir 1982;357:183.

20 Leese T, Neoptolemos JP, Carr-Locke DL. Successes, failures, early complications and their management following endoscopic sphincterotomy: results in 394 consecutive patients from a 3 single centre. Brf Surg 1985;72:215.

21 Peel ALG, Bourke JB, Hermon-Taylor J, MacLean ADW, Mann CV, Ritchie HD. How should î the common bile duct be explored? Ann R Coll Surg Engl 1975;56:124-34

22 Rattner DW, Warshaw AL. Impact of choledochoscopy on the management of choledocholithiasis. Ann Surg 1981;194:76-9.

23 Larson RE, Hodgson JR, Priestley JT. The early and long term results of 500 consecutive explorations of the common duct. Surg Gynecol Obstet 1966;122:744-50. 24 White TT, Bordley J. One percent incidence of recurrent gallstones six to eight years after
manometric cholangiography. Ann Surg 1978;188:562-9.

25 Baker AR, Neoptolemos JP, Leese T, Fossard DP. Choledochoduodenostomy and transduodenal 음 sphincteroplasty and sphincterotomy for common bile duct calculi: results in 246 patients. Surg Gynecol Obstet (in press)

26 McPherson GAD, Benjamin IS, Hodgson HJF, Bowley NB, Allison DJ, Blumgart LH. Preoperative percutaneous transhepatic biliary drainage: the results of a controlled trial. Brf Surg $T$ operative percu

27 Armstrong CP, Dixon JM, Taylor TV, Davies GC. Surgical experience of deeply jaundiced patients with bile duct obstruction. Brf Surg 1984;71:234-8

28 Gregg JA, De Girolami P, Carr-Locke DL. Effects of sphincteroplasty and endoscopic sphincterotomy on the bacteriologic characteristics of the common bile duct. Am $\mathcal{f}$ Surg $\vec{\oplus}$ 1985;149:668-71.

29 Keighley MRB. Micro-organisms in the bile. A preventable cause of sepsis after biliary surgery. Ann R Coll Surg Engl 1977;59:328-34.

30 Strachan CJL, Black J, Powis SJA, et al. Prophylactic use of cephazolin against wound sepsis after cholecystectomy. BrMed f 1977;i:1254-6.

31 Finnis D, Rowntree T. Choledochoscopy in the exploration of the common bile duct. Brf Surg 1977;64:61-4.

32 Ashby BS. Operative choledochoscopy in common bile duct surgery. Ann R Coll Surg Engl ڤ్

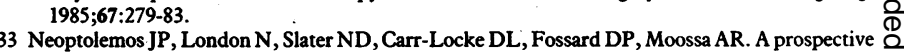
study of ERCP and endoscopic sphincterotomy in the diagnosis and treatment of gallstone acute pancreatitis. Arch Surg 1986;121:697-702.

(Accepted 6fanuary 1987)

\section{YEARS AGO}

The Progres Médical of July 9th publishes a paper by Drs. Regnard and Loye on the examination of the head and body of a convict immediately after his decapitation by the guillotine. The prisoner was calm to the last, and not pale, even when his neck was fixed ready to receive the fatal knife. Two seconds after decapitation the cheeks were still rosy, the eyes wide open, with moderately dilated pupils, the mouth firmly closed. No fibrillary contractions could be observed. When a finger was placed close to one eye, no change of expression took place; but on touching an eye or the tips of the lashes, during the first five seconds, the lids closed just as in life. This reflex action could not be elicited from the sixth second after decapitation. The jaws were tightly clenched, and could not be opened by manual force; no similar muscular contraction could be detected in the trunk or extremities. One minute after death the face began to turn pale, the trunk remained flaccid, the carotids continuing to throw out blood remaining in the circulatory area. At the end of four minutes the face was quite pale, the upper lids were half closed, the jaws less firmly clenched than before. Irritation of the cut surfaces of the spinal cord failed to produce reflex movements either in the trunk or on the face. For twenty minutes there was no change; then the necropsy was begun. There were signs of old pleurisy and alcoholism. The heart beat actively. On opening the pericardium, the ventricles and auricles continued to pulsate for twenty-five minutes; the former then ceased to beat, but the auricles went on for forty minutes longer. Thus the heart beat for an hour after decapitation. Then its chambers were laid open; the left ventricle was firmly contracted, the right relaxed. There was emphysema at the edges of the left lung, as is nearly always observed after death by the guillotine. $\supset$ There were bubbles of air in the vessels of the pia mater, and much air in the $N$ subarachnoid space. The knife had passed through the lower part of the fourth cervical vertebra. These researches show that not a trace of 0 consciousness remains two seconds after beheading; that reflex movements of the cornea can be excited for a few seconds; that the heart may beat for an 을 hour, the auricles continuing to pulsate alone for over half that period; and $\tilde{\omega}$ that, putting aside the reflex movements of the eyelid, the contraction of the 0 jaws and the jets of blood from the carotids, it seemed in this case as though $\mathrm{a}_{0}$ corpse had been decapitated, so inert were the remains of the convict. The $\frac{}{\odot}$ entry of air into the inextensible and incompressible cranial cavity, after the $\stackrel{\odot}{-}$ escape of blood from its vessels, was only to be expected. Drs. Regnard and Loye note how calm and free even from physiological death-struggle 0 symptoms is death by the guillotine. There is not even asphyxia; death is rather due to inhibition similar to that described by $M$. Brown-Séquard in $\frac{?}{\mathbb{D}}$ animals who succumb to certain irritations of the nervous system. In this $\stackrel{\Omega}{2}$ country we take on ourselves the responsibility of destroying life judicially. That so grave a task should be done as mercifully as possible is self-evident. 8 Hanging is a very different matter from decapitation. Anglo-Saxon sentiment $\frac{0}{0}$ is against the headsman; but surely a contrivance for a "mort calme et sans agonie" might be devised, to replace the ill-favoured gallows. (British $\frac{0}{\partial}$ Medical fournal 1887;ii:195.) 